resultant sympathetic excitation, will inhibit the milk ejection reflex. Since the same procedures inhibit the milk ejection effect of posterior pituitary extract, it is likely that the effect of adrenaline is, at least in part, on the mammary gland itself. Dr. A. G. Lewis dealt with recent work on the secretion of the antidiuretic hormone in normal man. It is satisfying to know that many of the laboratory findings are being confirmed on the human. After eighteen hours of dehydration a normal subject had posterior pituitary hormone in the circulation with an antidiuretic activity equal to (approximately) $20 \mathrm{mU}$. of 'Pitressin'. It seems unlikely that the $5 \mathrm{mU} . / \mathrm{ml}$. of antidiuretic substance which have been detected by rat assay of human serum have any physiological action. Direct assay in the human subject has shown that human serum contains less than $0.1 \mathrm{mU} . / \mathrm{ml}$. after twelve hours of dehydration. Emotional stimuli, the intravenous infusion of acetylcholine, or of hypertonic saline, nicotine, morphine, anæsthesia and surgical operations and syncope may all produce large releases of the antidiuretic hormone in man.

The final speaker at the symposium, Dr. J. E. Cates, described the results of an investigation, in collaboration with Dr. O. Garrod, on fifteen patients with diabetes insipidus. 'Pitressin' tests separate the rare 'Pitressin'-resistant cases. Water deprivation gives results which vary in degree. Hickey and Hare's test with hypertonic saline may be nullified by an osmotic diuresis. Nicotine intravenously causes little or no antidiuresis when given in doses large enough to cause antidiuresis in normal subjects; larger doses usually cause some antidiuresis. The effect of nicotine in clinical diabetes insipidus supports the belief that nicotine stimulates the secretion of the antidiuretic hormone. The response to large doses suggests that the lesion to the supraopticohypophysial system is often not complete.

'van Dyke, H. B., Chow, B. F., Greep,' R. O., and Rothen, A., J. Pharmacol., 74, 190 (1942).

"Livermore, A. H., and du Vigneaud, V., J. Biol. Chem., 180, 365 (1949).

- Pierce, J. G., and du Vigneaud, V., J. Biol, Chem. 182, 359 (1950).

- Pierce, J. G., and du Vigneaud, V., J. Biol. Chem., 186, 77 (1950).

5 Turner, R. A., Pierce, J. G., and du Vigneaud, V., J. Biol. Chem., 191, 21 . A., Pier.

- Cross, B. A., and Harris, G. W., Nature, 166, 994 (1950).

' Cross, B. A., and Harris, G. W., J. Endocrinol., 8, 148 (1952),

${ }^{8}$ Andersson, B., Acta Physiol. Scand., 23, 1 (1951).

\section{LONG ASHTON RESEARCH STATION REPORT FOR 1950}

$\mathrm{T}$ HE plant pathologist and the engineer tend to run their separate ways, sparing a modicum of liaison for each other, but rarely understanding the subject of plant pathological engineering as a whole. The annual report of the Agricultural and Horticultural Research Station, Long Ashton, Bristol*, is perhaps most noteworthy for a determined attempt to consider the problems of the plant pathologist and engineer together. H. G. H. Kearns and N. G. Morgan publish an abridged specification of an experimental 'air-flow' small-volume drift sprayer and duster. This is designed to investigate the most efficient method of conveying very small drops of concentrated control

* University of Bristol. Annual Report of the Agricultural and Horticultural Research Station (the National Fruit and Cider Institute), Long Ashton, Bristo materials to their disease targets, thus dispensing with large volumes of liquid, obtaining better penetration of the spray or dust cloud into foliage, and withal bringing great economy of the fungicide or insecticide. This material is fed into the blast from a fan delivering a large volume of air at low pressure.

New conceptions must not, however, be allowed to overshadow the solid worth of papers on more usual subjects. Nutritional studies include investigations on zine and copper deficiencies of crop plants (E. J. Hewitt and E. W. Jones), work on iron metabolism in plants by the same authors contributing separate papers, and research on molybdenum and nitrate status in relation to yield and ascorbic acid levels in cauliflower (S. C. Agarwala; W. Plant). The wealth of detail and of interaction in all these results is summarized in the introduction to the report by the director of the Station, Prof. T. Wallace (pp. 13 15). L. C. Luckwill and D. Woodcock have a preliminary report on the nature of the hormone which occurs in the endosperm of developing apple seed. It is, inter alia, acidic, heat stable, soluble in ether and water, is destroyed by hydrolysis with strong acid or alkali, and cannot be identical with indolylacetic acid. A further report on pruning systems and tree shape on yield and quality of apples is given by R. M. Jarrett. Any pruning reduces yield; but normal winter pruning improves quality. Allington and Cox's Orange Pippins oropped better as modified leader trees; but Worcester Pearmain gave more produce as an open-centre tree. Continuing their studies of the nutrition of the black currant, C. Bould and E. Catlow find that yield varied as leaf nitrogen status, which decreased according to the following order of manurial treatments : nitrogen plus phosphorus $>$ sewage sludge $>$ nitrochalk plus compost $>$ straw sludge compost $>$ farmyard manure $>$ no manure. D. J. D. Nicholas and W. A. Forster consider the effects of copper, zinc, lead, cobalt, nickel and manganese in excess on tomatoes and other crop plants. This is an important study, for excesses of 'micro' elements figure in advisory work in addition to deficiencies of these elements.

Long-term work on spray materials superior to lime-sulphur for the control of apple scab has been continued by R. J. W. Byrde and R. W. Marsh. They found that glyoxalidine $341-C$ at 1 quart per 100 gallons equalled the standard lime-sulphur treatments on Cox's Pippin, and was less phytotoxic. The new spray was also less damaging to foliage of Lane's Prince Albert and Stirling Castle than lime sulphur. A phthalimide preparation $(S R-406)$ promises good fungicidal performance and freedom from phytotoxicity.

F. W. Beech and S. W. Challinor discuss changes in the pectin and nitrogen contents of apple juices as a first part of a larger study of maceration and defecation in cider making. Fermentation of ciders can also be controlled by centrifuging; L. F. Burroughs and S. W. Challinor consider the mechanism of this action in scme detail. B. T. P. Barker continues his investigation of cider yeast floras with a paper on that of Kingston Black ciders. Margaret E. Kieser and A. Pollard discuss the effect of fruit storage on the processing of apple juice, and, with C. F. Timberlake, the effect of manurial treatment on the composition of black currants. Other shorter papers are included in the report, which is edited by R. W. Marsh, and numerous half-tone and line illustrations help to maintain its usual high standard of production. 